\title{
Low-Skilled Unemployment, Capital-Skill Complementarity and Embodied Technical Progress*
}

\author{
E. Moreno-Galbis ${ }^{\dagger} a n d$ H.R. Sneessens ${ }^{\ddagger}$
}

\begin{abstract}
Models developed by recent economic literature do not manage to account simultaneously for the three main stylized facts observed in many EU countries since the mid-seventies: (i) the increase in the overall unemployment rate; (ii) the difference between high-skilled and low-skilled unemployment; (iii) the stability of relative wages. This paper focuses on these issues. We construct an intertemporal general equilibrium model seeking to reproduce these facts. We consider two types of jobs and two types of workers. We allow for job competition between high- and low-skilled workers on the low-skilled segment of the labor market and for on-the-job search. Matching processes are represented by matching functions à la Pissarides. Low-skilled search intensities are endogenous and high-skilled workers decide on the amount of effort they devote to search in each labor market segment. Biased technological change is introduced via embodied technical progress and capital-skill complementarity. The model is calibrated and simulated to evaluate the impact of various types of shocks. The model reproduces quite well the unemployment rate changes and the relative wage stability observed over the past two decades.
\end{abstract}

Keywords: skill mismatch, equilibrium unemployment, skill biased technological progress, ladder effect, macro dynamics

JEL classification: E24, J21, J23

${ }^{*}$ We would like to thank seminar participants at the IZA Summer School 2003, Jamboree 2003 (Pompeu Fabra University) and two anonymous referees. We are especially indebted to Francois Langot for very useful suggestions. Any remaining errors are ours.

${ }^{\dagger}$ Corresponding author. Eva Moreno-Galbis is Professor of Economics at the Université du Maine (Avenue O. Messiaen, 72085 Le Mans Cedex 9, France) and associate researcher at CEPREMAP (Paris, France). Email: eva.moreno-galbis@univ-lemans.fr

${ }^{\ddagger}$ H.R. Sneessens is Professor of Economics at the Université Catholique de Louvain and Université Catholique de Lille. 


\section{Introduction}

The rise in unemployment observed in many European countries over the past decades has been particularly strong among low-skilled workers. One possible interpretation for these uneven changes in unemployment variations is biased technological progress. If investment in new technologies raises the relative demand for skilled workers ${ }^{1}$, low-skilled unemployment increases unless the variation in relative demands is compensated by a change in relative wages or in relative labor supplies. Biased technological change combined with relative wage rigidities may thus lead to "skill mismatch" and thereby, to higher low-skilled unemployment rates (see table 1). However, more and more attention has recently been paid to an alternative explanation in terms of job competition. If high-skilled workers compete with low-skilled ones for lowskilled jobs, but the opposite is not true, purely aggregate shocks can have strong asymmetric unemployment effects by generating the so-called ladder effect. The interest for this alternative view has arisen from the observation that all unemployment rates have increased, while a biased technological change should a priori decrease unemployment of high-skilled workers, at least if wage-wage interactions are not too strong. In many OECD countries, investment in human capital (education) has significantly increased despite a stable wage premium (see for instance Muysken and ter Weel (1999)). Youngsters invest more in human capital not because the relative wage of high-skilled on complex jobs has increased, but rather because a higher education level increases the number of job opportunities ${ }^{2}$.

Several authors examine this issue. Gautier (2002) develops a stylized partial equilibrium model with two types of jobs and two types of workers and wage bargaining. He focuses on the stationary state properties of the model and emphasizes the diversity of effects that can be obtained

\footnotetext{
${ }^{1}$ There is wide evidence suggesting that technological progress may have substantially increased the relative demand for skilled workers (see for instance Autor, Katz, and Krueger (1998), Berman, Bound, and Griliches (1994), or Machin and Van Reenen (1998)).

${ }^{2}$ Recent empirical work suggest that the proportion of "overqualified" workers is far from negligible although hard to evaluate. Hartog (2000) collects empirical results from various studies about the level of job competition ("overeducation") in several EU countries. Depending on the methodology used and the country surveyed, this overeducation is estimated to be between $10 \%$ and $30 \%$ during the first half of the nineties. Moreover, they also show that overeducation increased over the last decades (except in UK). Forgeot and Gautié (1997) report that, in France, the proportion of overeducated workers has strongly increased between 1986 and 1995, particularly among women and young workers looking for a first job. Following their study, between 1986 and 1995 the proportion of French workers with an university diploma being overqualified in their job increased from $6.6 \%$ to $18.7 \%$. Moreover, in 1995, more than $24 \%$ of young women were overqualified.
} 


\begin{tabular}{|c|c|c|c|c|c|c|c|}
\hline & \multicolumn{3}{|c|}{$\begin{array}{l}\text { LOW-SKILLED UNEMPLOYMENT RATES } \\
\text { (difference wrt. average unemployment rate) }\end{array}$} & \multicolumn{4}{|c|}{ RELATIVE WAGES } \\
\hline & 1970-1979 & 1980-1989 & 1990-1999 & & 1980-1984 & $1985-1989$ & 1990-1995 \\
\hline Belgium & 0.7 & 2.7 & 6.2 & D1/D5 & .. & 71.6 & 71.8 \\
\hline France & 1.6 & 8.5 & 11.3 & D1/D5 & 61.1 & 61.9 & 62.0 \\
\hline Germany & 2.7 & 7.2 & 7.8 & D1/D5 & 68.0 & 70.7 & 72.9 \\
\hline United Kingdom & 1.4 & 7.4 & 6.5 & D1/D5 & 63.1 & 59.6 & 57.4 \\
\hline United States & 2.5 & 3.4 & 5.1 & D1/D5 & 51.5 & 48.7 & 48.5 \\
\hline
\end{tabular}

D1/D5: ratio of the upper earnings limit of the first decile of workers to the upper limit of the fifth decile.

Source concerning unemployment rates: Sneessens and Shadman (2000) for Belgium; Fonseca, Maillard, and Sneessens (1998) for France; Buttler and Tessaring (1993) for Germany; Nickell and Quintini (2001) for the United Kingdom (only male workers); Bureau of Labor Statistics database for the United States.

Source concerning relative wages: OECD Employment Outlook 1996 chapter 3. For Belgium we have information only between 1985-1993 and for Germany between 1983-1993.

Table 1: Low-skilled unemployment rates (difference with respect to average unemployment rates) and relative wages in five OECD countries (in percent).

as a result of the externalities introduced via the matching function. Dolado, Felgueroso, and Jimeno (2000) use a similar approach with a simpler albeit more realistic representation of wage determination to provide a quantitative analysis of the Spanish case. They calibrate a stationary equilibrium model to evaluate the job competition effect triggered by the dramatic increase in the proportion of skilled workers that took place in the late eighties. Similar models are also considered in Albrecht and Vroman (2002) and Dolado, Jansen, and Jimeno (2002). Collard, Fonseca, and Muñoz (2002) provide a first attempt to include this type of quantitative analysis in a dynamic general equilibrium setup. Pierrard and Sneessens (2002) use a similar setup with on-the-job search and endogenous search intensities for high-skilled workers. Their model is able to explain a significant part of the unemployment rise observed in Belgium over the last twenty years by simply changing two parameters: the relative productivity of high-skilled workers and the proportion of high-skilled workers in the total labor force.

One of the main difficulties in these models is to account simultaneously for the three main stylized facts observed in many EU countries since the mid-seventies: (i) the increase in the overall unemployment rate; (ii) the difference between high-skilled and low-skilled unemployment; (iii) the stability of relative wages. This paper focuses on these issues. It builds on Pierrard and Sneessens (2002). Compared to their model, our methodological contribution is threefold. In- 
stead of assuming that low-skilled wages are indexed on high-skilled ones, we allow separate wage bargaining for all workers. Second, by endogenizing search intensities of low-skilled workers we are able to capture a kind of discouragement effect understood as a decrease in the intensity of search rather than as duration concept (there is no duration in our model). Moreover, because high-skilled workers choose endogenously the effort devoted to each labor market segment we are able to measure the evolution of the job competition effect. Finally, we introduce a biased technological progress resulting from the combination of embodied technical change with capital-skill complementarity. Authors like Greenwood, Hercowitz, and Krussel (1997) or Mairesse, Cette, and Kocoglu (2000) find that technological progress has become increasingly incorporated in new capital goods. We thus distinguish between embodied and disembodied technological change and endogenize the first of them. The importance of the capital-skill complementary relationship has also been signaled by many empirical studies (see Berman, Bound, and Griliches (1994), Machin and Van Reenen (1998) or Krusell et al. (2000)).

When calibrated on the Belgian economy, the model reproduces the three stylized facts mentioned above. We obtain a significant discouragement effect (decrease in search intensity) for low-skilled workers induced by the reduction in their employment opportunities due to the lower demand for simple jobs and the increased job competition. The reduced demand is explained by the skill-biased technological progress which favors the relative productivity of complex jobs and thus the opening of complex vacancies. The increased job competition results from the fall in the labor market tension of the complex segment (the number of job seekers in this segment increases relatively more than the number of vacancies) which leads high-skilled workers to devote more search effort to the simple segment.

The paper is organized as follows. In section 2 we present the model. We describe labor market flows, workers and firms behaviors, and wage bargaining. In section 3 we calibrate the model on Belgian data for 1996. We examine the properties of the model by simulating its responses to various types of shocks. We next set the technological and labor force composition variables to their 1976 values and check the ability of the model to reproduce the stylized facts. Moreover, we also quantify the contribution of the low-skilled's discouragement effect, job competition and wage bargaining to the predicting performance of the model. Finally, we analyze the effects of various policy measures. Section 4 concludes. 


\section{The model}

The structure of the model is based on an earlier work by Pierrard and Sneessens (2002). The economy consists of two broad categories of agents, firms and households. We distinguish two types of households; each type is defined by the skill level (high or low) of its members. All members of a household supply inelastically one unit of labor; they may be employed or unemployed $^{3}$.

We distinguish three types of firms: two types of intermediate good firms, producing respectively high- and low-tech intermediate goods with labor as sole input, and one representative final firm, combining capital and the two intermediate goods to produce an homogeneous final good. The final good can be used for consumption or capital accumulation. The production of high-tech intermediate goods involves complex tasks that can only be carried out by high-skilled workers. The production of low-tech intermediate goods consists of simpler tasks that can be carried out by both high- or low-skilled workers. There is thus a double heterogeneity as in Gautier (2002): heterogeneity of jobs (complex vs simple) and heterogeneity of workers (high- vs low-skilled).

There are three types of markets: labor, goods and capital. On the labor side, we distinguish between the complex and the simple job markets, where the complex jobs can only be occupied by high-skilled workers and simple jobs by both high- and low-skilled workers. For each type of job, we assume an exogenous job destruction rate and represent the matching process by a standard matching function (Cobb-Douglas). Because they know that their application will always be turned down, low-skilled job seekers never apply for complex jobs. High-skilled unemployed workers may look for both types of jobs. The effort devoted to search in each segment depends on the employment possibilities and wages. Furthermore, the set of parameter values adopted guarantees the absence of corner solutions in the benchmark simulation, i.e. there is always a number of high-skilled workers in simple jobs. High-skilled workers hired on a simple job may continue searching for a complex job (on-the-job search). Low-skilled unemployed workers may search more or less intensively for a simple job, depending on its attractiveness compared to home production. All good markets (the two intermediate goods and the final good markets) are assumed to be perfectly competitive. The price of the final good is normalized to one. On the

\footnotetext{
${ }^{3}$ The representative household formulation amounts to assuming that workers of a given group are perfectly insured against their own individual unemployment risk. This simplification is common in the literature and is needed to keep the model tractable.
} 
capital market, the supply is determined by the stock of capital previously accumulated by the household (as explained in section 2.5 all capital stock is owned by the high-skilled household). The interest rate adjusts to make the quantity demanded by the representative final firm equal to this predetermined capital stock.

Labor market flows are detailed in the following subsection. Next we successively discuss the behaviors of the intermediate and final firms, the mechanisms of biased technological change and capital accumulation, the behaviors of high- and low-skilled households and, finally, the wage determination processes.

\subsection{Labor market flows}

Let $N_{t}^{c}$ and $N_{t}^{s}$ represent total employment in complex and simple jobs, respectively. Simple jobs can be occupied by high- $\left(N_{t}^{s h}\right)$ or low-skilled $\left(N_{t}^{s l}\right)$ workers, so that $N_{t}^{s}=N_{t}^{s h}+N_{t}^{s l}$. Normalizing the total labor force to one and denoting by $\alpha$ the exogenous ${ }^{4}$ proportion of highskilled workers in the total labor force yields the following accounting identities:

$$
N_{t}^{c}+N_{t}^{s h}+U_{t}^{h}=\alpha, \quad \text { and } \quad N_{t}^{s l}+U_{t}^{l}=1-\alpha,
$$

where $U_{t}^{h}$ and $U_{t}^{l}$ denote the number of high- and low-skilled unemployed job-seekers respectively. Evidently, considering only two broad categories of workers (high- and low-skilled) and two types of jobs, implies neglecting an important part of the observed ladder effect (overqualified workers in a job) since as remarked by Cockx and Dejemeppe (2004), the competition is more intense inside these large groups. However, on the aim of simplicity we prefer to keep this minimalist representation of the labor market where job competition is measured as the proportion of simple jobs occupied by high-skilled workers (or equivalently the proportion of potentially employed low-skilled workers that are crowded-out by high-skilled).

Let the number of complex and simple job matches be denoted by $M_{t}^{c}$ and $M_{t}^{s}$ respectively. We assume that the number of such matches is a function of the number of corresponding job vacancies $\left(V_{t}^{c}\right.$ and $V_{t}^{s}$ ) and effective job seekers (the number of job seekers weighted by their search efficiencies), that is, we use the following two matching functions:

$$
M_{t}^{c}=M^{c}\left(V_{t}^{c}, s c_{t} U_{t}^{h}+s o_{t} N_{t}^{s h}\right) \quad \text { and } \quad M_{t}^{s}=M^{s}\left(V_{t}^{s}, s h_{t} U_{t}^{h}+s l_{t} U_{t}^{l}\right),
$$

\footnotetext{
${ }^{4}$ An endogenous $\alpha$ would require the model to consider human capital formation and education issues, which is beyond the scope of the present paper.
} 
where $s c_{t}, s o_{t}, s h_{t}$ and $s l_{t}$ stand for the search efficiency of each type of job seeker. Both functions are assumed to be linear homogeneous (Cobb-Douglas). We assume that every period, both the high- and the low-skilled unemployed workers spend a certain amount of time having what we call an active life. In other words, every period, a constant fraction of time is spent on searching for a job or doing other productive activities (in our case, domestic production), while the rest of the time is devoted to non-productive activities (such as sleeping, eating, etc.). The amount of time spent in active life is the same for high- and low-skilled workers, and we normalize it to one.

We assume that a high-skilled unemployed worker devotes all her active time searching for a job, however, given the conditions prevailing on the labor market (wages, probabilities to find jobs,...), she allocates this time between searching for a complex job $\left(0 \leq e h_{t} \leq 1\right)$ and for a simple job $\left(0 \leq 1-e h_{t} \leq 1\right)$. Remark that in the high-skilled worker's case, the total amount of time devoted to search is exogenous, since we assume that she spends all her active time searching for a job. However, the worker chooses endogenously the search effort devoted to each labor market segment (because a high-skilled worker can apply to simple and complex jobs, we make the hypothesis that she never gets discouraged from search, and simply allocates more or less effort to each labor market segment depending on the employment possibilities of the segment). High-skilled on simple jobs spend a fraction $\left(0 \leq e o_{t} \leq 1\right)$ of their leisure time (normalized to 1) searching for a complex job. Besides, a low-skilled unemployed splits her active time between searching for a job in the simple segment $\left(0 \leq e l_{t} \leq 1\right)$ and staying at home doing domestic activities $\left(0 \leq 1-e l_{t} \leq 1\right)$. Because they know that their application will always be turned down, low-skilled job seekers never apply for complex jobs, so when they are not looking for a job in the simple segment, they simply stay at home doing domestic activities. When employment opportunities in the simple segment fall the worker gets discouraged and spends more time doing domestic activities. This contrasts with the assumption made for high-skilled workers, who do not suffer the discouragement effect. Search efficiencies, $s o_{t}, s c_{t}, s h_{t}$ and $s l_{t}$ are concave and increasing functions of the search efforts, $e o_{t}, e h_{t}, 1-e h_{t}$ and $e l_{t}$, respectively. We define labor market tensions as the ratio between the number of vacancies and the number of effective job seekers and denote them by $\vartheta_{t}^{c}$ and $\vartheta_{t}^{s}$ respectively, where:

$$
\vartheta_{t}^{c} \equiv \frac{V_{t}^{c}}{s c_{t} U_{t}^{h}+s o_{t} N_{t}^{s h}} \quad \text { and } \quad \vartheta_{t}^{s} \equiv \frac{V_{t}^{s}}{s h_{t} U_{t}^{h}+s l_{t} U_{t}^{l}} .
$$

With linear homogeneous matching functions, the probabilities $p_{t}^{c}$ and $p_{t}^{s}$ of finding a complex 
and a simple job per unit of search intensity can be respectively written as follows:

$$
p_{t}^{c}=\frac{M_{t}^{c}}{s c_{t} U_{t}^{h}+s o_{t} N_{t}^{s h}}=p^{c}\left(\vartheta_{t}^{c}\right) \quad \text { and } \quad p_{t}^{s}=\frac{M_{t}^{s}}{s h_{t} U_{t}^{h}+s l_{t} U_{t}^{l}}=p^{s}\left(\vartheta_{t}^{s}\right) .
$$

The probabilities $q_{t}^{c}$ and $q_{t}^{s}$ of filling a complex and a simple job vacancy are similarly given by:

$$
q_{t}^{c}=\frac{M_{t}^{c}}{V_{t}^{c}}=q^{c}\left(\frac{1}{\vartheta_{t}^{c}}\right) \quad \text { and } \quad q_{t}^{s}=\frac{M_{t}^{s}}{V_{t}^{s}}=q^{s}\left(\frac{1}{\vartheta_{t}^{s}}\right) .
$$

The probability that a simple job is filled is the sum of the probabilities of hiring a high-skilled worker and a low-skilled worker:

$$
q_{t}^{s h}=\frac{s h_{t} U_{t}^{h}}{s h_{t} U_{t}^{h}+s l_{t} U_{t}^{l}} q_{t}^{s} \quad \text { and } \quad q_{t}^{s l}=\frac{s l_{t} U_{t}^{l}}{s h_{t} U_{t}^{h}+s l_{t} U_{t}^{l}} q_{t}^{s} .
$$

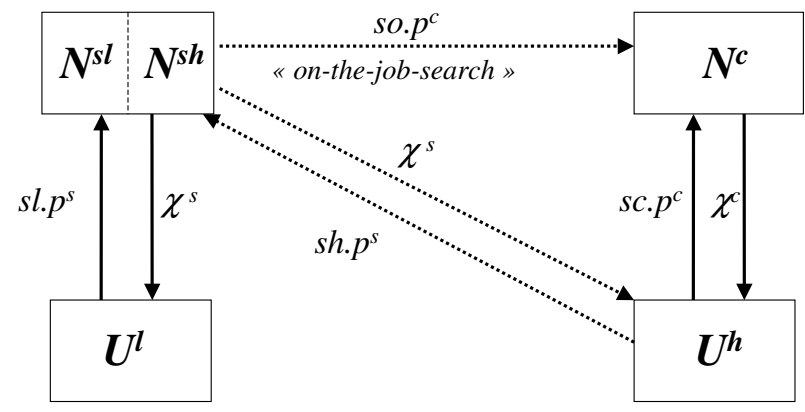

Figure 1: Labor market flows and transition probabilities.

Finally, we assume two exogenous job destruction rates, $\chi^{c}$ (for the complex jobs) and $\chi^{s}$ (for the simple jobs), which implies for each type of job and worker the following employment dynamics (in terms of vacancies and job-seekers' search effort respectively):

$$
\begin{aligned}
N_{t+1}^{c} & =\left(1-\chi^{c}\right) N_{t}^{c}+q_{t}^{c} V_{t}^{c}, \\
& =\left(1-\chi^{c}\right) N_{t}^{c}+p_{t}^{c}\left[s c_{t} U_{t}^{h}+s o_{t} N_{t}^{s h}\right] . \\
N_{t+1}^{s h} & =\left(1-\chi^{s}-s o_{t} p_{t}^{c}\right) N_{t}^{s h}+q_{t}^{s h} V_{t}^{s}, \\
& =\left(1-\chi^{s}-s o_{t} p_{t}^{c}\right) N_{t}^{s h}+p_{t}^{s} s h_{t} U_{t}^{h} . \\
N_{t+1}^{s l} & =\left(1-\chi^{s}\right) N_{t}^{s l}+q_{t}^{s l} V_{t}^{s}, \\
& =\left(1-\chi^{s}\right) N_{t}^{s l}+p_{t}^{s} s l_{t} U_{t}^{l} .
\end{aligned}
$$

Figure 1 summarizes these labor market flows and transition probabilities. Armed with these definitions and notations, we can now describe the behaviors of the firms and households. 


\subsection{Intermediate firms}

We use the standard one-job-one-firm representation. Each intermediate firm can open either a complex or a simple vacancy. Let us denote the asset value of a vacant (resp. filled) complex job by $W_{N_{t}^{c}}^{V}\left(\right.$ resp. $W_{N_{t}^{c}}^{F}$ ). The cost of opening a complex vacancy equals $v_{t}^{c}$ per period. A filled complex job produces each period one unit of complex intermediate good sold at a price $c_{t}^{c}$; the wage paid to the worker is denoted $w_{t}^{c}$. The asset values of the vacant and filled complex jobs are then given by:

$$
\begin{aligned}
& W_{N_{t}^{c}}^{V}=-v_{t}^{c}+\mathrm{E}_{t}\left[\tilde{\beta}_{t+1}\left(q_{t}^{c} W_{N_{t+1}^{c}}^{F}+\left(1-q_{t}^{c}\right) W_{N_{t+1}^{c}}^{V}\right)\right], \\
& W_{N_{t}^{c}}^{F}=c_{t}^{c}-w_{t}^{c}+\mathrm{E}_{t}\left[\tilde{\beta}_{t+1}\left(\left(1-\chi^{c}\right) W_{N_{t+1}^{c}}^{F}+\chi^{c} W_{N_{t+1}^{c}}^{V}\right)\right],
\end{aligned}
$$

where $\tilde{\beta}_{t+1}$ is the firm's discount factor (defined in section 2.5 ).

Simple job vacancies can be filled with either a high-skilled or a low-skilled worker. The two workers may however have different productivity. Let $W_{N_{t}^{s}}^{V}$ denote the asset value of a vacant simple job. The asset value of a filled simple job will be denoted $W_{N_{t}^{s h}}^{F}$ when filled by a highskilled worker and $W_{N_{t}^{s l}}^{F}$ when filled by a low-skilled worker. Let $v_{t}^{s}$ denote the vacancy cost per period, $c_{t}^{s}$ the selling price, $w_{t}^{s h}$ and $w_{t}^{s l}$ the wage paid to the high- and low-skilled worker respectively. Asset values are then given by:

$$
\begin{aligned}
W_{N_{t}^{s}}^{V} & =-v_{t}^{s}+\mathrm{E}_{t}\left[\tilde{\beta}_{t+1}\left(q_{t}^{s h} W_{N_{t+1}^{s h}}^{F}+q_{t}^{s l} W_{N_{t+1}^{s l}}^{F}+\left(1-q_{t}^{s h}-q_{t}^{s l}\right) W_{N_{t+1}^{s}}^{V}\right)\right], \\
W_{N_{t}^{s h}}^{F} & =c_{t}^{s}-w_{t}^{s h}+\mathrm{E}_{t}\left[\tilde{\beta}_{t+1}\left(\left(1-\chi^{s}-p_{t}^{c} s o_{t}\right) W_{N_{t+1}^{s h}}^{F}+\left(\chi^{s}+p_{t}^{c} s o_{t}\right) W_{N_{t+1}^{s}}^{V}\right)\right], \\
W_{N_{t}^{s l}}^{F} & =\nu \cdot c_{t}^{s}-w_{t}^{s l}+\mathrm{E}_{t}\left[\tilde{\beta}_{t+1}\left(\left(1-\chi^{s}\right) W_{N_{t+1}^{s l}}^{F}+\chi^{s} W_{N_{t+1}^{s}}^{V}\right)\right],
\end{aligned}
$$

where the parameter $\nu$ allows different productivity levels for high- and low-skilled workers $(\nu$ may a priori be larger or smaller than unity). We finally assume the usual free entry conditions (the firms open vacancies until no benefit can be obtained from an additional vacancy):

$$
W_{N_{t}^{c}}^{V}=W_{N_{t}^{s}}^{V}=0
$$

\section{$2.3 \quad$ Final firm}

The representative final firm uses capital $\left(K_{t}\right)$, complex and simple intermediate goods $\left(Q_{t}^{c}\right.$ and $Q_{t}^{s}$ respectively) in order to produce a final good via a linear homogeneous production function 
$F\left(K_{t}, Q_{t}^{c}, Q_{t}^{s}\right)$. The firm's optimization problem can be represented by:

$$
\max _{K_{t}, Q_{t}^{c}, Q_{t}^{s}} F\left(K_{t}, Q_{t}^{c}, Q_{t}^{s}\right)-c_{t}^{K} K_{t}-c_{t}^{c} Q_{t}^{c}-c_{t}^{s} Q_{t}^{s},
$$

where $c_{t}^{K}$ is the usage cost of capital, while $c_{t}^{c}$ and $c_{t}^{s}$ stand, respectively, for the price of complex and simple intermediate goods. The first order optimality conditions are given by the standard marginal productivity conditions:

$$
F_{K_{t}}=c_{t}^{K}, \quad F_{Q_{t}^{c}}=c_{t}^{c}, \quad F_{Q_{t}^{s}}=c_{t}^{s},
$$

where $F_{X_{t}}$ stands for the first derivative of $F$ with respect to $X_{t}$. In the rest of the paper, we assume a Cobb-Douglas production function with constant returns to scale:

$$
F\left(K_{t}, Q_{t}^{c}, Q_{t}^{s}\right)=z\left[K_{t}\right]^{1-\mu}\left[\left(Q_{t}^{c}\right)^{\theta_{t}^{c}}\left(Q_{t}^{s}\right)^{\theta_{t}^{s}}\right]^{\mu}, \quad \theta_{t}^{c}+\theta_{t}^{s}=1
$$

where $z$ represents total factor productivity and $1-\mu$ is the capital share. As discussed below, we allow the productivity coefficients, $\theta_{t}^{c}$ and $\theta_{t}^{s}$, of the two intermediate inputs to vary over time. Notice that the equilibrium conditions in the intermediate goods markets imply:

$$
Q_{t}^{c}=N_{t}^{c} \quad \text { and } \quad Q_{t}^{s}=N_{t}^{s h}+\nu N_{t}^{s l},
$$

so that changes in the values of $\theta_{t}^{c}$ and $\theta_{t}^{s}$ induce changes in the marginal productivity (in value added terms) of complex and simple jobs respectively.

\subsection{Skill-Bias}

The empirical evidence reveals that the use of new technologies is associated to an increased relative demand for skilled labor, as a result of either technological requirements (see Berman, Bound, and Griliches (1994) for an example on the U.S. economy and Machin and Van Reenen (1998) for European countries) or induced organizational changes (see for instance Caroli and Van Reenen (2001) and Bresnahan, Brynjolfsson, and Hitt (2002)). This suggests that the variation in the demand for skilled labor should best be seen as resulting from a combination of embodied technological progress and capital-skill complementarity. The empirical relevance of these two aspects has been emphasized by Greenwood, Hercowitz, and Krussel (1997) or Mairesse, Cette, and Kocoglu (2000) for embodied technological progress and by Berman, Bound, and Griliches (1994), Krusell et al. (2000), Lindquist (2004) or Machin and Van Reenen (1998), among others, for capital-skill complementarity. In line with this empirical literature, 
we consider that the change in the relative demand for high-skilled workers is associated to embodied technological progress.

We model the embodiment process by allowing new investment goods to be more productive than older ones, which is simple to formalize and, at the same time, seems quite intuitive. Following Boucekkine, del Rio, and Licandro (2003), we write the law of motion of capital ${ }^{5}$ as:

$$
K_{t+1}-K_{t}=e_{t} I_{t}-\delta K_{t}, \quad 0<\delta<1
$$

where $I_{t}$ denotes investment expenditures and $\delta$ is the exogenous depreciation rate of capital. The variable $e_{t}$ is an index measuring the marginal contribution of investment expenditures to the aggregate capital stock (it stands for the embodied technological progress). The term $1 / e_{t}$ is interpreted as the relative price of new capital goods.

We represent embodied technical progress by a simple learning-by-doing (LBD) process, where the productivity of the capital good sector, measured by $e_{t}$, is a positive function of the size of that sector, measured by $K_{t}$ :

$$
e_{t}=e_{0} K_{t}^{\gamma}, \quad \gamma \geq 0,
$$

where $e_{0}$ is the scale parameter and $\gamma$ measures the efficiency of the LBD process. Equations (20) and (21) describe this process: for each unit of final good invested in period $t$, we obtain $e_{t}>e_{t-1}$ units of capital. These productivity gains lead to lower capital good prices, which stimulates investment, increases the total capital stock, and leads to further productivity gains (via the learning process described in equation (21)). This process comes to an end when these productivity gains $\left(\Delta e_{t}\right)$ are more than compensated by the decrease in the marginal productivity of capital $\left(\Delta F_{K_{t}}\right)$.

The complementary relationship between capital and skills is introduced by allowing the use of new technologies to change the relative productivity (in value added terms) of skilled labor:

$$
\frac{\theta_{t}^{c}}{\theta_{t}^{s}}=a_{0} e_{t}^{a_{1}}, \quad a_{1} \geq 0
$$

An upturn in $e_{t}$ improves the productivity of new investment goods and complex intermediate goods (which stimulates the relative demand for high-skilled labor). This specification endogenizes the observed complementarity between new technologies and skilled labor and keeps the

\footnotetext{
${ }^{5}$ Boucekkine, del Rio, and Licandro (2003) show that this simple representation can be obtained from an explicit vintage model.
} 
Cobb-Douglas production function framework supported by the aggregate evidence and used in most dynamic macro models ${ }^{6}$.

\subsection{Households}

The household decisions bear on consumption and savings and on job search efforts. To avoid untractable ex post heterogeneity issues, most general equilibrium models with search assume that workers are perfectly insured against individual unemployment risks. Assuming a large representative household is a simple way of introducing such an assumption. For our purpose, it is important though to distinguish at least two types of households, a high- and a low-skilled household. Employment probabilities and expected wage incomes are quite different for highand low-skilled workers. This will affect their search behaviors, as well as the negotiated wages. To simplify we assume that the whole capital stock is owned by the high-skilled (high-income) household. This amounts to assuming that the low-skilled (low-income) household consumes its current income in every period.

\section{The representative high-skilled household}

The members of the high-skilled household can be either unemployed, employed on a complex job getting paid a wage $w_{t}^{c}$, or employed on a simple job getting paid a wage $w_{t}^{s h}$. The decision variables of the household are the consumption level of each of its members and the amount of time devoted to search in each segment for those who are unemployed or employed on a low-paid simple job. We assume that unemployed job seekers devote all their free time (normalized to unity) to search; they choose the fraction of this time, $e h_{t}$, that will be devoted to the complex market. Similarly, workers on a simple job devote a fraction, eot, of their leisure time to onthe-job search. The optimization problem of the representative high-skilled household can be written as the following Bellman equation:

$$
\mathcal{W}_{t}^{H}=\max _{C_{t}^{h}, e h_{t}, e o_{t}}\left\{\alpha \mathcal{U}\left(\frac{C_{t}^{h}}{\alpha}\right)-N_{t}^{s h} \mathcal{D}\left(e o_{t}\right)+\beta \mathrm{E}_{t}\left[\mathcal{W}_{t+1}^{H}\right]\right\}
$$

\footnotetext{
${ }^{6}$ Manacorda and Petrongolo (1999) estimate a production function with two types of labor for several OECD countries and conclude that the Cobb-Douglas hypothesis cannot be rejected; biased technical progress takes the form of an exogenous change in the productivity coefficients. The Cobb-Douglas specification is also motivated in the RBC literature by the observation that the capital share remains stable in the long run.
} 
subject to constraints (1), (7-b), (8-b) and to the flow budget constraint :

$$
w_{t}^{c} N_{t}^{c}+w_{t}^{s h} N_{t}^{s h}+w_{t}^{u} U_{t}^{h}+c_{t}^{k} K_{t}+\Pi_{t}=\frac{1}{e_{t}}\left(K_{t+1}-(1-\delta) K_{t}\right)+C_{t}^{h}+T_{t} .
$$

$\mathcal{W}_{t}^{H}$ is a function of the initial values of the three state variables $K_{t}, N_{t}^{c}, N_{t}^{s h} ; \mathcal{U}($.$) is an increas-$ ing and concave function of per capita consumption $\left(C_{t}^{h}\right.$ measures thus the total consumption of the high-skilled household); $\mathcal{D}($.$) is an increasing and convex function of the amount of leisure$ time devoted to on-the-job search; $\beta$ is a psychological discount factor. The resources of the high-skilled household include wage incomes, an unemployment benefit $w_{t}^{u}$, the rents from capital plus the profits $\Pi_{t}$ redistributed by the intermediate good firms. Investment expenditures are equal to net capital accumulation times the relative price of new capital goods $1 / e_{t}$ (see (20)). $T_{t}$ represents a lump-sum tax levied on the high-skilled household to finance government expenditures.

Let us define $r_{t}$ as the net interest rate measured in units of capital ${ }^{7}$. More precisely:

$$
r_{t}=c_{t}^{k} \cdot e_{t}-\delta
$$

Let us also define the asset values (from the high-skilled household's point of view) of an additional complex or simple job as:

$$
W_{N_{t}^{c}}^{H}=\frac{1}{\mathcal{U}_{C_{t}^{h}}} \frac{\partial \mathcal{W}_{t}^{H}}{\partial N_{t}^{c}} \quad \text { and } \quad W_{N_{t}^{s h}}^{H}=\frac{1}{\mathcal{U}_{C_{t}^{h}}} \frac{\partial \mathcal{W}_{t}^{H}}{\partial N_{t}^{s h}},
$$

respectively. The first-order optimality conditions can then be written as follows:

$$
\begin{aligned}
\mathcal{U}_{C_{t}^{h}} & =\beta \mathrm{E}_{t}\left[\left(1+r_{t+1}\right) \frac{e_{t}}{e_{t+1}} \mathcal{U}_{C_{t+1}^{h}}\right], \\
0 & =\mathrm{E}_{t}\left[p_{t}^{c} s c_{e h_{t}} \tilde{\beta}_{t+1} W_{N_{t+1}^{c}}^{H}-p_{t}^{s} s h_{1-e h_{t}} \tilde{\beta}_{t+1} W_{N_{t+1}^{s h}}^{H}\right], \\
\frac{\mathcal{D}_{e o_{t}}}{\mathcal{U}_{C_{t}^{h}}} & =p_{t}^{c} s o_{e o_{t}} \mathrm{E}_{t}\left[\tilde{\beta}_{t+1}\left(W_{N_{t+1}^{c}}^{H}-W_{N_{t+1}^{s h}}^{H}\right)\right],
\end{aligned}
$$

\footnotetext{
${ }^{7}$ The optimal capital stock is defined by the usual optimality condition:
}

$$
F_{K_{t}}=c_{t}^{K}
$$

where $F_{K_{t}}$ stands for the marginal productivity of capital and $c_{t}^{K}$ for the capital usage cost. We should keep in mind, however, that the marginal productivity of capital, $F_{K_{t}}$, is defined in terms of final goods, while the rate of return to investors is defined in terms of capital goods. The relative price of the latter is $1 / e_{t}$. Hence, the marginal cost of capital, $c_{t}^{K}$, is related to the rate of return by:

$$
c_{t}^{K}=\frac{1}{e_{t}}\left(r_{t}+\delta\right) \text {. }
$$


where the discount factor $\tilde{\beta}_{t+1}$ is defined by:

$$
\tilde{\beta}_{t+1}=\beta \frac{\mathcal{U}_{C_{t+1}^{h}}}{\mathcal{U}_{C_{t}^{h}}} .
$$

From the envelope theorem, we can obtain the following additional dynamic relationships:

$$
\begin{aligned}
& W_{N_{t}^{c}}^{H}=\left(w_{t}^{c}-w_{t}^{u}\right)+\left(1-\chi^{c}-p_{t}^{c} s c_{t}\right) \mathrm{E}_{t}\left[\tilde{\beta}_{t+1} W_{N_{t+1}^{c}}^{H}\right] \\
& \quad-p_{t}^{s} s h_{t} \mathrm{E}_{t}\left[\tilde{\beta}_{t+1} W_{N_{t+1}^{s h}}^{H}\right] \\
& W_{N_{t}^{s h}}^{H}=\left(w_{t}^{s h}-w_{t}^{u}\right)-\mathcal{D}\left(e o_{t}\right) / \mathcal{U}_{C_{t}^{h}}+p_{t}^{c}\left(s o_{t}-s c_{t}\right) \mathrm{E}_{t}\left[\tilde{\beta}_{t+1} W_{N_{t+1}^{c}}^{H}\right] \\
& \quad+\left(1-\chi^{s}-s o_{t} p_{t}^{c}-p_{t}^{s} s h_{t}\right) \mathrm{E}_{t}\left[\tilde{\beta}_{t+1} W_{N_{t+1}^{s h}}^{H}\right] .
\end{aligned}
$$

\section{The representative low-skilled household}

While high-skilled unemployed workers can search for a job on both the complex and the simple segments, low-skilled unemployed workers have only the choice between searching for a simple job or doing some "domestic production". By assumption, the low-skilled household accumulates no capital. Its sole decision variable is the fraction of time $e l_{t}$ that the unemployed worker devotes to job search rather than to domestic activities. Its optimization problem can thus be written as the following Bellman equation:

$$
\mathcal{W}_{t}^{L}=\max _{e l_{t}}\left\{(1-\alpha) \mathcal{U}\left(\frac{C_{t}^{l}}{1-\alpha}\right)+\beta \mathrm{E}_{t}\left[\mathcal{W}_{t+1}^{L}\right]\right\}
$$

subject to (9-b) and the flow budget constraint:

$$
C_{t}^{l}=w_{t}^{s l} N_{t}^{s l}+U_{t}^{l}\left[w_{t}^{u}+\left(1-e l_{t}\right) y_{t}^{d}\right] .
$$

$\mathcal{W}_{t}^{L}$ is a function of the initial value of the state variable $N_{t}^{s l}, C_{t}^{l}$ is the total amount consumed by the low-skilled household and $y_{t}^{d}$ is the productivity of unemployed workers on domestic activities.

The first order optimality condition can be written as follows:

$$
y_{t}^{d}=p_{t}^{s} s l_{e l_{t}} \mathrm{E}_{t}\left[\hat{\beta}_{t+1} W_{N_{t+1}^{s l}}^{L}\right]
$$

where $\hat{\beta}_{t+1}=\beta \mathcal{U}_{C_{t+1}^{l}} / \mathcal{U}_{C_{t}^{l}}$ is the discount factor of the low-skilled household and $W_{N_{t}^{s l}}^{L}=$ $\frac{1}{\mathcal{U}_{C_{t}^{l}}} \frac{\partial \mathcal{W}_{t}^{L}}{\partial N_{t}^{s l}}$ the asset value of an additional simple job at time $t$. From the envelope theorem we obtain:

$$
W_{N_{t}^{s l}}^{L}=\left(w_{t}^{s l}-w_{t}^{u}-\left(1-e l_{t}\right) y_{t}^{d}\right)+\left(1-\chi^{s}-p_{t}^{s} s l_{t}\right) \mathrm{E}_{t}\left[\hat{\beta}_{t+1} W_{N_{t+1}^{s l}}^{L}\right]
$$




\subsection{Wage determination}

There are three types of matches (high-skilled worker on a complex or a simple job; low-skilled worker on a simple job). We assume that the wage rate is in each case determined at the beginning of every period by a Nash bargaining process, which yields the following sharing rules:

$$
\begin{aligned}
W_{N_{t}^{c}}^{H} & =\eta^{c}\left(W_{N_{t}^{c}}^{H}+W_{N_{t}^{c}}^{F}\right), \\
W_{N_{t}^{s h}}^{H} & =\eta^{s h}\left(W_{N_{t}^{s h}}^{H}+W_{N_{t}^{s h}}^{F}\right), \\
W_{N_{t}^{s l}}^{L} & =\eta^{s l}\left(W_{N_{t}^{s l}}^{L}+W_{N_{t}^{s l}}^{F}\right) .
\end{aligned}
$$

where $\eta^{i}$ for $i=c, s h, s l$, represent the workers' bargaining power.

It is worth making several remarks concerning this bargaining process. First of all, it must be noticed that wage determination in the presence of on-the-job search can become a complicated issue because it involves three parties: the earlier employer, the worker and the new employer. Burdett and Mortensen (1998) or Postel-Vinay and Robin (2002) deal with this trilateral issue explicitly. However, in this paper we follow, Hall (2005) and we keep the exposition simple by assuming that the conventions of the labor market require that a worker who has come in contact with a prospective new employer while still working for an earlier employer, quit her existing job before negotiating wages with the new employer. This assumption is no more than an equilibrium selection rule and it implies that a job found by on-the-job search has the same present value of wages as one found during a spell of unemployment. This, together with the assumption that wages in complex jobs are always larger than those in simple jobs ${ }^{8}$, avoids the non-convexity problem of the set of feasible payoffs treated in Shimer (2005). Evidently the wage bargaining process must be interpreted in this context from a macro perspective. From this point of view we can assume that most wages are determined at the national or sectoral level through collective bargaining with unions (see section 3.1 for further details on the wage determination process in Belgium), implying that the outside option taken as reference is the unemployment benefit.

Second, as underlined latter on in this paper, in the presence of job competition and on-the-job search this Nash bargaining sharing rule does not necessarily lead to an efficient result, even

\footnotetext{
${ }^{8}$ This is essentially an assumption on productivities, firms offering simple vacancies can never bid more than firms offering complex vacancies.
} 
when the Hosios-Pissarides condition is satisfied. Finally, remark that the model introduces a downward rigidity in low-skilled wages via the presence of an outside option (domestic productivity) that is increasing over time ${ }^{9}$. This formalization tries to capture the progressive rise in low-skilled reservation wage over the past decades, which has fostered the observed relative wage rigidity in European countries. Besides, our representation also avoids wages to absorb the whole impact in case of shock.

\section{Model calibration and simulations}

In this section we calibrate the model and use deterministic simulation exercises to illustrate its properties and gain insights on the effects of various types of shocks. The emphasis will be on the effects of labor force composition and biased technological change and their interactions with the "institutional" settings over the period 1976-1996.

\subsection{Specification and calibration}

The matching function on each job market is represented by the usual Cobb-Douglas specification with constant returns to scale:

$$
M_{t}^{c}=m^{c}\left(V_{t}^{c}\right)^{1-\lambda^{c}}\left(s c_{t} U_{t}^{h}+s o_{t} N_{t}^{s h}\right)^{\lambda^{c}} \quad \text { and } \quad M_{t}^{s}=m^{s}\left(V_{t}^{s}\right)^{1-\lambda^{s}}\left(s h_{t} U_{t}^{h}+s l_{t} U_{t}^{l}\right)^{\lambda^{s}}
$$

for complex and simple jobs respectively. The Cobb-Douglas specification for the matching process is quite standard in the literature since it is mathematically simply to deal with and it seems to provide a good approximation of the real matching process (see Petrongolo and Pissarides (2001)). We follow Manacorda and Petrongolo (1999) and use also a constant returns to scale Cobb-Douglas function with three inputs to represent the technological constraint faced by the representative final firm ${ }^{10}$ (see equations (18) and (19)). The skill-biased change is seen as the consequence of embodied technological progress and capital-skill complementarity (see equations (21) and (22)). As in many RBC models, we represent the instantaneous utility of consumption by the logarithm of consumption expenditures. The leisure cost of on-the-job search is proportional to the amount of time spent and home productivity is assumed to be

\footnotetext{
${ }^{9}$ See Hall (2005) or Hall and Milgrom (2005) for alternative approaches on wage stickiness.

${ }^{10}$ The choice of a Cobb-Douglas production function is also justified by the available estimations we have for Belgium concerning the Cobb-Douglas productivity coefficients $\mu \theta^{c}$ and $\mu \theta^{s}$ (see Sneessens and Shadman (2000)).
} 
equal to a fraction $\psi$ of aggregate productivity. More formally:

$$
\mathcal{U}_{t}=\ln c_{t}, \quad \mathcal{D}_{t}=\tau e o_{t} \quad \text { and } \quad y_{t}^{d}=\psi \frac{y_{t}}{N_{t}}
$$

Search efficiencies are represented by linear functions of the square root of the time devoted to search:

$$
\begin{array}{rr}
s o_{t}=\phi_{0}^{o}+\phi_{1}^{o} \sqrt{e o_{t}} & \text { On-the-job search efficiency } \\
s c_{t}=\phi_{0}^{c}+\phi_{1}^{c} \sqrt{e h_{t}} & \text { and } \quad s h_{t}=\phi_{0}^{h}+\phi_{1}^{h} \sqrt{1-e h_{t}}
\end{array}
$$

High-skilled unemployed search efficiencies

on each labor market segment

$$
s l_{t}=\phi_{0}^{l}+\phi_{1}^{l} \sqrt{e l_{t}} \quad \text { Low-skilled unemployed search efficiency }
$$

We follow Pissarides (2000) and assume that recruiting costs are proportional to aggregate productivity: $v_{t}^{c}=v_{0}^{c} \frac{y_{t}}{N_{t}}$ and $v_{t}^{s}=v_{0}^{s} \frac{y_{t}}{N_{t}}$.

The parameters of the model are whenever possible set to values compatible with the available empirical evidence. The parameters for which no empirical estimates are available are chosen so as to reproduce the situation observed in Belgium in the mid nineties (1996). As most EU countries, the Belgian economy was then neither in a recession nor in a boom. In terms of employment performance, the Belgian economy is in the EU average and quite representative of a typical European economy.

The numerical values of the parameters are reported in table 2 . The reference period is the quarter. The elasticity of output with respect to capital coincides with the capital share in total income; it is set to the standard value $1-\mu=0.33$ used in the RBC literature. The depreciation rate $\delta$ is set to $2.5 \%$. We assume that high- and low-skilled workers are equally productive on simple jobs $(\nu=1)$. This particular choice has little impact on the predictions of the model. We fix the parameters describing the embodied technical progress so as to reproduce the change in the relative price of investment goods observed in Belgium during the period 1976-1996 (a decline rate of around $-20 \%$ according to data provided by the Belgian Statistical Institute). We normalize the relative price to unity in 1976 (that is, $e_{0}=1$ and $\gamma=0$ in 1976) and set the 1996 value of $\gamma$ to 0.0705 (implying $e_{t}=1.23$ in 1996). The effects of embodied technical progress on the relative demand for high- and low-skilled workers are determined by the values of the 


\begin{tabular}{|l|c|r||c|r|}
\hline & Symbol & Value & Symbol & Value \\
\hline Production & $z$ & 1 & $\mu$ & 0.66 \\
& $\nu$ & 1.00 & $\delta$ & 0.025 \\
& $e_{0}$ & 1.00 & $\gamma$ & 0.071 \\
Labor force composition & $a_{0}$ & 0.42 & $a_{1}$ & 10.2 \\
Preferences & $\alpha$ & 0.67 & & \\
Domestic productivity & $\beta$ & 0.99 & $\tau$ & 0.30 \\
Search efficiencies & $\psi$ & 0.17 & & \\
& $\phi_{0}^{l}$ & 0.25 & $\phi_{1}^{l}$ & 1.00 \\
& $\phi_{0}^{h}$ & 0.25 & $\phi_{1}^{h}$ & 1.00 \\
Matching efficiencies & $\phi_{0}^{c}$ & 0.25 & $\phi_{1}^{c}$ & 0.50 \\
Bargaining power & $\phi_{0}^{o}$ & 0.25 & $\phi_{1}^{o}$ & 0.50 \\
Vacancy costs & $m^{c}$ & 0.38 & $\lambda^{c}$ & 0.50 \\
Job destruction rates & $m^{s}$ & 0.38 & $\lambda^{s}$ & 0.50 \\
Average replacement ratio & $\eta^{c}$ & 0.50 & & \\
\hline & $\eta^{s h}$ & 0.50 & $\eta^{s l}$ & 0.50 \\
& $\chi_{0}^{c}$ & 0.55 & $v_{0}^{s}$ & 0.10 \\
& & 0.03 & $\chi^{s}$ & 0.05 \\
& & & \\
\hline
\end{tabular}

Table 2: Numerical parameter values (year of reference: 1996).

parameters $a_{0}$ and $a_{1}$. These values are chosen so as to reproduce the 1976 and 1996 values of the Cobb-Douglas coefficients $\mu \theta^{c}$ and $\mu \theta^{s}$ reported in Sneessens and Shadman (2000).

We define the high-skilled group by an educational attainment level at least equal to a uppersecondary degree and set $\alpha=0.67$, the 1996 value reported by Sneessens and Shadman (2000) for Belgium. As in most RBC models, consumers's psychological discount factor $\beta$ is set to 0.99, implying a steady state real interest rate of 0.01 (real interest rate of $4 \%$ per annum). The domestic productivity parameter $\psi$ is fixed at 0.17 (i.e. the domestic productivity of a low-skilled worker is equal to $17 \%$ of the average aggregate productivity), a value which seems reasonable and gives a realistic relative wage for the 1996 benchmark simulation $\left(w^{s l} / w^{c}=62 \%\right.$, a value close to the relative wage estimated in OECD (1996)).

Our representation of the wage determination process remains of course simplified compared to the complexity of the Belgian system. In Belgium, there are three levels of wage negotiation: 
the intra-sectoral (national) level, the sectoral level and the individual level. Every two years, negotiations at the intra-sectoral level determine the legal minimum wage, as well as the "wage norm". More regularly, wage negotiations are also held within the different economic sectors where the legal minimum wage and the wage norm are taken respectively as the lower and upper bounds: sectoral minimum wages cannot be lower than the legal minimum wage and sectoral wage increases cannot exceed the limits fixed by the wage norm. Eventually, wages may, at each period, be (re)negotiated at the individual level. As a consequence, in 1995, only $2 \%$ of Belgian workers were paid at the legal minimum wage while around $10 \%$ of them were paid at one of the minimum wages. In Belgium the estimated gross minimum wage (taking into account the sectoral minimum wages) represents around $60 \%$ of the average wage. We thus fix the net Katz index (defined as the ratio of the gross minimum wage to the average wage) to 0.58 , so that we obtain for 1996 a minimum wage of 0.70 . This value is bigger than the value associated to domestic activities, meaning that it is always in the interest of a low-skilled worker to accept a job paid at the minimum wage rather than staying at home. On the other side, we realize that the average wage earned in simple jobs is around 0.8 , and whatever the shocks we introduce, it never falls below the minimum wage (probably due to the rigidity introduced by the presence of an indexed domestic productivity).

We have four search efficiency equations, two for each segment of the labor market. Given the lack of data on these search efficiency parameters, we try to reduce the degrees of freedom in the calibration process by imposing identical parameter values for a given segment, which leaves four values to fix. The simple job market search efficiency coefficients have been chosen so as to normalize low-skilled workers' search efficiency to unity in 1976 and have a sensitivity to labor market tightness in the order of magnitude estimated by Patacchini and Zenou (2003) (around 0.3). The complex market search efficiency coefficients, the disutility parameter $\tau$, the two matching efficiency parameters and the vacancy cost parameters $\left(v_{0}^{c}\right.$ and $\left.v_{0}^{s}\right)$ are given values to reproduce the 1996 values of the high- and low-skilled unemployment rates $(6.8 \%$ and $20.1 \%$, respectively), the probabilities of filling a vacant complex or simple job ( $q_{t}^{c}$ and $q_{t}^{s}$, around 0.4; see Delmotte, Hootegem, and Dejonckheere (2001)) and the probabilities of finding a complex or a simple job (values of $p_{t}^{s}$ and $p_{t}^{c}$ such that the probability to find a job is around $20 \%$ for a low-skilled worker and 40\% for a high-skilled-worker; see Cockx and Dejemeppe (2004)). Our calibration of $v_{0}^{c}$ and $v_{0}^{s}$ implies that total vacancy costs represent $3.5 \%$ of output in the reference simulation. 
We follow most authors and set the parameter determining the worker's share in a match surplus equal to the coefficient of unemployment in the matching function (see for instance Merz (1995) and Andolfatto (1996) $)^{11}$. The latter is set at 0.5, a value obtained in many empirical estimates of the Cobb-Douglas matching function (see Petrongolo and Pissarides (2001)) and that provides reasonable results in our simulations. Calibrations for the average replacement ratio $(b u=34 \%)$ and the two job destructions rates $\left(\chi^{c}=3 \%\right.$ and $\left.\chi^{s}=5 \%\right)$ are based on estimations by Van der Linden and Dor (2001) for the Belgian economy.

A result of this calibration exercise is that the proportion of high-skilled workers in simple jobs equals $7.2 \%$. Even if this result contrasts with the $24 \%$ job competition effect found in Denolf, Denys, and Simoens (2001) for the Belgian economy, we must take into account that our theoretical setup considers job competition only between two groups of workers: high- and low-skilled, whereas job competition has been documented to be more intense inside groups. Our results seem though to be coherent with previous estimations made for Belgium ${ }^{12}$.

Because the parameters $a_{0}$ and $a_{1}$ are chosen so as to reproduce the 1976 and 1996 values reported in Sneessens and Shadman (2000) of the Cobb-Douglas production function coefficients, $\mu \theta^{c}$ and $\mu \theta^{s}$, and because the parameters for which there is no empirical evidence are chosen to mimic the situation in Belgium in 1996, it is not surprising to find a benchmark situation close to the actual data for 1996 (see table 5). Moreover, by assuming that low-skilled workers have

\footnotetext{
${ }^{11}$ This choice is typically motivated by the so-called Hosios-Pissarides efficiency condition. It is worth noting that in our setup with job competition and on-the-job search this condition may not be sufficient to ensure efficiency.

${ }^{12}$ Working with data concerning workers entering insured unemployment in Belgium, Cockx and Dejemeppe (2004) distinguish four labor market segments and find that, in average, $36 \%$ of dismissed workers who find a new job requiring less than upper secondary education are overeducated for the job. The overeducation indicator used is the share of hirings in jobs requiring less than upper secondary education that are filled by overeducated workers: $M_{t}^{s h} / M_{t}^{s}$, where $M_{t}^{s h}$ corresponds to the number of matches between workers having more than upper secondary education and jobs requiring less than this educational level, and $M_{t}^{s}$ stands for the total number of matches requiring less than upper secondary education. When the ratio $M_{t}^{s h} / M_{t}^{s}$ is computed for our framework, where only two labor market segments are distinguished, we find that $29 \%$ of hirings in simple jobs are filled by high-skilled workers. It must be noticed that, contrarily to Cockx and Dejemeppe (2004), we cannot measure the number of hirings in jobs requiring no education or elementary education that are filled by people with lower secondary education. By distinguishing only two labor market segments we slightly under-estimate the true job competition effect, which explains the difference between the $29 \%$ crowding-out effect predicted by our model and the $36 \%$ found by Cockx and Dejemeppe (2004).
} 
the possibility (outside option) to stay at home to do some domestic activities we introduce a rigidity in low-skilled relative wages, since the value of this domestic production has increased between 1976 and 1996. The relative rigidity of low-skilled wages together with the adopted calibration for $\mu \theta^{c}$ and $\mu \theta^{s}$, contribute to the good performances of the model in reproducing the variation of main macroeconomic magnitudes between 1976 and 1996. The numerical exercises developed in the following sections test the ability of our theoretical framework to capture the interactions between the economic variables and to reproduce the evolution of unemployment rates and relative wages observed in Belgium over the past decades.

\subsection{Technological shocks, labor force composition and unemployment}

We start examining the steady state effects of two different types of shocks in order to test the properties of the model. In table 3, we consider first a change in the labor force composition (an increase in the proportion of high-skilled in the total labor force, $\alpha$ ) and then, we look to the effects of an embodied technical shock (variation in $\gamma$ ). A sensitivity analysis on the effects of a biased technological shock is implemented in table 4. Finally, table 5 displays the historical simulation of Belgian unemployment rates and relative wages, whereas table 6 quantifies the contribution of the discouragement effect, the job competition effect and the separate wage bargaining to the ability of the model to reproduce these historical evolutions of the labor market. We briefly comment the results ${ }^{13}$ of each exercise.

\section{Labor force composition}

A rise in the proportion of high-skilled workers in the total labor force $(\alpha)$ increases the probability to fill a complex job, and thus stimulates the opening of complex vacancies. The more important number of complex jobs improves the marginal productivity of simple jobs, increasing simple wages and stimulating search effort of low-skilled workers $\left(e l_{t}\right)$.

On the other side, the higher demand for simple jobs raises the probability of hiring high-skilled workers on this type of jobs. Their search effort on the simple segment is then stimulated and job competition increases. All in all, the low-skilled unemployment rate decreases and so does the high-skilled unemployment rate.

\footnotetext{
${ }^{13}$ For the variables expressed in percentage, deviations from the benchmark are absolute deviations; for the variables expressed in level, deviations from the benchmark are relative deviations.
} 


\begin{tabular}{|c|c|c|c|c|c|c|}
\hline & $\begin{array}{l}\text { Low-skilled } \\
\text { search } \\
\text { efficiency }\end{array}$ & $\begin{array}{l}\text { High-skilled } \\
\text { unemployment } \\
\text { rate }\end{array}$ & $\begin{array}{l}\text { Low-skilled } \\
\text { unemployment } \\
\text { rate }\end{array}$ & $\begin{array}{l}\text { Aggregate } \\
\text { unemployment } \\
\text { rate }\end{array}$ & $\begin{array}{l}\text { Relative } \\
\text { wage }\end{array}$ & $\begin{array}{c}\text { Job } \\
\text { competition }\end{array}$ \\
\hline $\begin{array}{l}\text { Benchmark simulation } \\
\text { corresponding to the year } 1996\end{array}$ & $55.7 \%$ & $7.0 \%$ & $21.0 \%$ & $11.7 \%$ & $62.1 \%$ & $7.2 \%$ \\
\hline $\begin{array}{l}\text { Proportion of high-skilled } \\
\text { workers: } \alpha=0.67 \rightarrow \alpha=0.70 \\
\text { Efficiency of the embodied } \\
\text { technical progress learning } \\
\text { process: } \gamma=0.71 \rightarrow \gamma=0.74\end{array}$ & +12.8 & -0.4 & -3.2 & -1.6 & +2.7 & +2.4 \\
\hline
\end{tabular}

Table 3: Steady state effects (deviations from the benchmark) of an increase in the proportion of high-skilled workers and of a biased technological progress.

\section{Biased technological shock}

The increase in $\gamma$ improves the learning efficiency of the embodied technical progress production process (from each unit of investment the economy is able to obtain more capital than before). Capital accumulation is then accelerated, which via the capital-skill complementary relationship stimulates the demand for complex jobs. This, together with the rise in complex wages, results in an increased search effort of high-skilled unemployed $\left(e h_{t}\right)$ and employed $\left(e o_{t}\right)$ on the complex segment of the labor market.

The larger share of complex jobs in the production function implies a reduction in the share of simple jobs, leading to a fall in the demand of this type of jobs as well as in their productivity. Wages decrease and so does the search effort in the simple segment of both low-skilled unemployed $\left(e l_{t}\right)$ and high-skilled unemployed $\left(1-e h_{t}\right)$. Because both categories of workers benefit from simple jobs, a downturn in their demand affects both types of unemployment rates. This, together with the more important proportion of high-skilled workers searching in the complex segment, explains the rise in high-skilled unemployment in spite of the larger demand for complex jobs.

To sum up, this simulation suggests that skill biased technological progress in a context where the labor market is characterized by the presence of job competition on the simple segment and on-the-job search, can foster an increase in high-skilled unemployment rates. Since this result may seem counterintuitive we proceed to analyze it in more detail. 


\begin{tabular}{|c|c|c|c|c|c|c|c|}
\hline & $\begin{array}{l}\text { High-skilled } \\
\text { search } \\
\text { efficiency } \\
\text { complex seg. }\end{array}$ & $\begin{array}{l}\text { High-skilled } \\
\text { search } \\
\text { efficiency } \\
\text { simple seg. }\end{array}$ & $\begin{array}{l}\text { High-skilled } \\
\text { unemployment } \\
\text { rate }\end{array}$ & $\begin{array}{l}\text { Low-skilled } \\
\text { unemployment } \\
\text { rate }\end{array}$ & $\begin{array}{c}\text { Aggregate } \\
\text { unemployment } \\
\text { rate }\end{array}$ & $\begin{array}{l}\text { Relative } \\
\text { wage }\end{array}$ & $\begin{array}{c}\text { Job } \\
\text { competition }\end{array}$ \\
\hline \multicolumn{8}{|c|}{ Benchmark simulation corresponding to the year 1996} \\
\hline 1996 & $74.7 \%$ & $35.0 \%$ & $7.0 \%$ & $21.0 \%$ & $11.7 \%$ & $62.1 \%$ & $7.2 \%$ \\
\hline \multicolumn{8}{|c|}{ Search efficiency parameter $\phi_{1}^{c}=0.25$} \\
\hline$\gamma=0.71 \rightarrow \gamma=0.74$ & -35.3 & +72.8 & -0.2 & +3.5 & +1.0 & -4.4 & +1.9 \\
\hline \multicolumn{8}{|c|}{ Search efficiency parameter $\phi_{1}^{h}=1.5$} \\
\hline$\gamma=0.71 \rightarrow \gamma=0.74$ & +0.1 & +4.9 & -0.0 & +3.6 & +1.2 & -3.5 & -0.5 \\
\hline \multicolumn{8}{|c|}{ Search efficiency parameters $\phi_{1}^{c}=0.25, \phi_{1}^{h}=1.5$} \\
\hline$\gamma=0.71 \rightarrow \gamma=0.74$ & -36.8 & +166.6 & -1.3 & +4.9 & +0.8 & -4.9 & +4.2 \\
\hline
\end{tabular}

Table 4: Steady state effects (deviations from the benchmark) of a biased technological under different search efficiency scenarios. 
The assumed calibration concerning the search efficiency parameters of high-skilled workers (essentially $\phi_{1}^{c}$ and $\phi_{1}^{h}$ ) guarantees that increases in the demand for complex jobs (mainly derived from improvements in the productivity of complex jobs) are accompanied by an upturn in the search effort $\left(e h_{t}\right)$ devoted by high-skilled workers to the complex segment. Because the search effort of high-skilled on the simple segment is computed as a residual of the active time not spent in looking for a job in the complex segment $\left(1-e h_{t}\right)$, an upturn in $e h_{t}$ is necessarily translated into a downturn of the search effort devoted to the simple segment. What happens if the search efficiency parameter values are modified in such a way that high-skilled workers become much more efficient when searching in the simple segment than when searching in the complex segment? In this context, if the worker devotes the same amount of effort to each labor market segment, search will be more efficient on the simple segment. The trade-off between spending one unit of time in the complex or in the simple segment, becomes now more favorable to the simple segment. Therefore, even if job opportunities and wages increase in the complex segment the worker may not search more intensively for a complex job since the opportunity cost of each unit of effort devoted to this segment has increased.

In table 4 we develop a sensitivity analysis on the effects of a given biased technological shock under three different scenarios:

- In the first scenario we assume that the search efficiency parameter on the complex segment, $\phi_{1}^{c}$, falls by $50 \%$ with respect to the benchmark situation $\left(\phi_{1}^{c}=0.25\right)$. The efficiency units obtained now from each unit of effort spent on the complex segment represent only $25 \%$ of those efficiency units that would have been obtained if the effort had been devoted to the simple segment. In this new context, even if the biased technical change promotes the opening of complex vacancies and the rise of complex wages, high-skilled workers prefer to spent more time searching on the simple segment where, thanks to their relatively more efficient search, they manage to crowd-out low-skilled job seekers (the proportion of high-skilled workers occupying simple jobs increases in spite of the reduction in the number of simple vacancies). High-skilled unemployment rate falls.

- In the second scenario, we assume that the search efficiency parameter of high-skilled in the simple segment increases by $50 \%$ to $\phi_{1}^{h}=1.5$, so that $\phi_{1}^{c} / \phi_{1}^{h}=0.5 / 1.5=0.33$. Because each unit of effort devoted to search in the simple segment is three times more efficient than if it had been devoted to search in the complex segment, we observe that even if 
employment opportunities and wages in the complex segment are stimulated by the skill biased technological change, high-skilled workers do not search more intensively in this segment.

- In the third scenario we combine the two previous scenarios, so that the already described effects are exacerbated. Even if employment conditions are deteriorated in the simple segment, high-skilled workers prefer to devote most of their search efforts to this segment, where they are relatively more efficient. The job competition effect reaches $11.4 \%$ and high-skilled unemployment rates fall.

In sum, for a skill biased technological shock to foster a reduction in high-skilled unemployment rates the required calibration for the search efficiency parameters must be such that, even when employment opportunities and wages are higher in the complex segment, high-skilled workers prefer to devote more effort to the simple segment. This result is completely counterintuitive, which makes us more confident on the estimations obtained with our initial calibration.

\subsubsection{Historical comparison}

The first row of table 5 reproduces the observed 1996 values of the proportion of high-skilled workers in the labor force $(\alpha)$, the share of complex jobs in the production function $\left(\mu \theta^{c}\right)$, the net skill-bias ${ }^{14}$, the high- and low-skilled unemployment rates, the relative wage $\left(w^{s l} / w^{c}\right)$ and an indicator of job competition $\left(N_{t}^{s h} /\left(N_{t}^{s h}+N_{t}^{s l}\right)\right)$. On the second row we display the change observed for these variables over the period 1976-1996.

The two last rows of table 5 contain the values obtained from the model. By construction (calibration) the 1996 values are close to the observed ones. The model performs also well in reproducing the changes observed during the 1976-1996 period: the increase in unemployment rates and the stability of relative wages.

Within the theoretical framework developed in this paper the previous results are interpreted as follows. The post-1975 period in Belgium was characterized by an increase in the proportion of high-skilled workers in the labor force (from $21.5 \%$ to $67 \%$ ), and by the rise in the decline rate of the investment good prices with respect to consumption prices (it attained values around $-20 \%$

\footnotetext{
${ }^{14}$ It is defined as the ratio of the relative productivity coefficient $\left(\mu \theta_{t}^{c}\right) /\left(\mu \theta_{t}^{s}\right)$ and the relative labor force $\alpha /(1-\alpha)$
} 


\begin{tabular}{|c|c|c|c|c|c|c|c|}
\hline & $\begin{array}{l}\text { Prop. of } \\
\text { high-skilled } \\
\text { in the } \\
\text { labor force }\end{array}$ & $\begin{array}{l}\text { Share complex } \\
\text { jobs in the } \\
\text { production } \\
\text { function }\end{array}$ & $\begin{array}{l}\text { Net } \\
\text { Skill } \\
\text { Bias }\end{array}$ & $\begin{array}{l}\text { High-skilled } \\
\text { unemployment } \\
\text { rate }\end{array}$ & $\begin{array}{l}\text { Low-skilled } \\
\text { unemployment } \\
\text { rate }\end{array}$ & $\begin{array}{c}\text { Relative } \\
\text { wage }\end{array}$ & $\begin{array}{c}\text { Job } \\
\text { competition }\end{array}$ \\
\hline \multicolumn{8}{|l|}{ Actual data } \\
\hline 1996 & 0.67 & 0.51 & 1.59 & $6.8 \%$ & $20.1 \%$ & $66 \%$ & n.a. \\
\hline $\begin{array}{c}\text { 1976-96 absolute } \\
\text { deviations }\end{array}$ & +0.45 & +0.33 & +0.20 & +2.1 & +13.3 & -0.0 & n.a. \\
\hline \multicolumn{8}{|c|}{ Model's simulation } \\
\hline 1996 & 0.67 & 0.51 & 1.77 & $7.0 \%$ & $21.0 \%$ & $62.1 \%$ & $7.2 \%$ \\
\hline $\begin{array}{c}\text { 1976-96 absolute } \\
\text { deviations }\end{array}$ & +0.45 & +0.32 & +0.25 & +2.1 & +13.3 & -3.4 & +5.8 \\
\hline
\end{tabular}

Table 5: Skill-bias, unemployment rates, relative wages and ladder effect in Belgium: comparing actual and simulated data.

during the considered period). When introducing in our model both phenomena, we observe that the acceleration of embodied technological progress ${ }^{15}$ over the past decades has stimulated complex jobs creation and simple jobs destruction, via the capital-skill complementary relationship. The increased demand for high-skilled workers in complex jobs has been satisfied by the large upturn in their supply. In contrast, the fall in the size of the low-skilled labor force has not been enough to compensate the massive destruction of simple jobs and the increased job competition. Low-skilled unemployment rises by 13.3 percentage points.

\subsubsection{Discouragement effect, separate wage bargaining and job competition}

As remarked in section 1, two of the main methodological contributions of this paper, are the introduction of endogenous search efforts on each labor market segment and a separate wage bargaining process. The former permits our model to capture the observed discouragement effect suffered by low-skilled workers over the past years (the decrease in employment opportunities and wages has led many low-skilled workers to reduce their intensity of search) as well as the increase in job competition on the simple segment. On the other hand, the presence of an outside option for low-skilled workers (domestic production) allows the separate wage bargaining process to reproduce the observed stability in relative wages. Actually, by allowing low-skilled workers to

\footnotetext{
${ }^{15}$ The relative price of investment goods is defined as $1 / e_{t}$, therefore an acceleration in the embodied technological progress results in a decline of this relative price.
} 
split their active time between searching for a job or staying at home doing domestic activities, we introduce a source of rigidity on the wage bargaining process, which combined with the downturn in the demand for simple jobs and job competition has promoted a rise in low-skilled unemployment rates over the past decades.

\begin{tabular}{|c|c|c|c|c|c|c|c|}
\hline & $\begin{array}{l}\text { Prop. of } \\
\text { high-skilled } \\
\text { in the } \\
\text { labor force }\end{array}$ & $\begin{array}{l}\text { Share complex } \\
\text { jobs in the } \\
\text { production } \\
\text { function }\end{array}$ & $\begin{array}{l}\text { Net } \\
\text { Skill } \\
\text { Bias }\end{array}$ & $\begin{array}{l}\text { High-skilled } \\
\text { unemployment } \\
\text { rate }\end{array}$ & $\begin{array}{l}\text { Low-skilled } \\
\text { unemployment } \\
\text { rate }\end{array}$ & $\begin{array}{l}\text { Relative } \\
\text { wage }\end{array}$ & $\begin{array}{c}\text { Job } \\
\text { competition }\end{array}$ \\
\hline \multicolumn{8}{|l|}{ Actual data } \\
\hline 1996 & 0.67 & 0.51 & 1.59 & $6.8 \%$ & $20.1 \%$ & $66 \%$ & n.a. \\
\hline $\begin{array}{c}\text { 1976-96 absolute } \\
\text { deviations }\end{array}$ & +0.45 & +0.33 & +0.20 & +2.1 & +13.3 & -0.0 & n.a. \\
\hline \multicolumn{8}{|c|}{ Simulation without discouragement effect: $s l=$ constant $=0.75$} \\
\hline 1996 & 0.67 & 0.52 & 1.79 & $6.7 \%$ & $12.3 \%$ & $54.4 \%$ & $6.6 \%$ \\
\hline $\begin{array}{l}\text { 1976-96 absolute } \\
\text { deviations }\end{array}$ & +0.45 & +0.32 & +0.28 & +2.5 & +4.2 & -10.0 & +4.8 \\
\hline \multicolumn{8}{|c|}{ Simulation without discouragement effect and indexation of simple wages: } \\
\hline \multicolumn{8}{|c|}{$w^{s l}=w^{s h}=\mathbf{0 . 6 0} \cdot w^{c}$ and $s l=\mathbf{c o n s t a n t}=\mathbf{0 . 7 5}$} \\
\hline 1996 & 0.67 & 0.52 & 1.77 & $7.2 \%$ & $17.4 \%$ & $60.0 \%$ & $6.2 \%$ \\
\hline $\begin{array}{l}\text { 1976-96 absolute } \\
\text { deviations }\end{array}$ & +0.45 & +0.32 & +0.25 & +3.7 & +12.1 & 0.0 & +4.3 \\
\hline \multicolumn{8}{|c|}{ Simulation without job competition: $s h \longrightarrow 0$} \\
\hline 1996 & 0.67 & 0.52 & 1.77 & $9.3 \%$ & $16.7 \%$ & $64.0 \%$ & $0.0 \%$ \\
\hline $\begin{array}{c}\text { 1976-96 absolute } \\
\text { deviations }\end{array}$ & +0.45 & +0.32 & +0.25 & +1.1 & +9.2 & -3.6 & 0.0 \\
\hline
\end{tabular}

Table 6: Skill-bias, unemployment rates, relative wages and ladder effect in Belgium: evaluating the importance of the discouragement effect and the relative wage rigidity.

The first two rows of the table reproduce the actual values observed for unemployment rates, relative wages and job competition in 1996, as well as, their variation between 1976 and 1996 . In the third and fourth rows of table 6 we assume a fixed search efficiency for low-skilled workers (no discouragement effect since $e l_{t}$ is not longer a decision variable), while we leave high-skilled search efficiencies on each market segment variable ${ }^{16}$. We keep the separate wage bargaining for each type of worker. The flexibility of wages ${ }^{17}$ together with the constant search efficiency

\footnotetext{
${ }^{16}$ The discouragement only affects low-skilled workers.

${ }^{17}$ In this new framework the effect of domestic production as a source of wage rigidity is smoothed due to the
} 
of low-skilled workers (who are not longer discouraged), fosters a reduction in unemployment levels and in its observed variation. Ignoring the rigidity of relative wages observed in Europe over the last 25 years as well as the discouragement effect of low-skilled workers, prevents thus the model from reproducing the evolution of unemployment rates.

The fifth and sixth rows of table 6, neglect the discouragement effect of low-skilled workers but introduce an indexation of wages in simple jobs $\left(w_{t}^{s h}\right.$ and $w_{t}^{s l}$ represent $60 \%$ of $\left.w_{t}^{c}\right)$, so as to eliminate the flexibility we had in the third and fourth rows of the table. These structural modifications lead to a reduction in the estimated low-skilled unemployment rates for 1996 with respect to actual data (the unemployment rate equals $17.4 \%$ instead of $20.1 \%$ ). Even if the ability of the model to reproduce unemployment rates in 1996 is deteriorated, its predicting performance concerning the variation of unemployment between 1976 and 1996 is not strongly damaged: the model predicts an increase in high- and low-skilled unemployment rates of +3.7 and +12.1 percentage points while the actual variation is +2.1 and +13.3 points, respectively. These estimations suggest that, while incorporating the discouragement effect improves the ability of the model to mimic unemployment levels for 1996, the observed unemployment variation between 1976 and 1996 mainly responds to the rigidity in relative wages.

The last two rows of the table summarize the labor market evolutions that would have been observed if the search efficiency of high-skilled workers on the simple segment converged to zero. In this context, low-skilled unemployment rates would have been reduced by more of 3 percentage points in 1996 with respect to actual data (while high-skilled unemployment raises). Moreover, in the absence of job competition the model predicts a variation of 9 percentage points in low-skilled unemployment rates, instead of the 12 points observed in actual data. Crowdingout of low-skilled workers by high-skilled plays therefore a relevant role in explaining low-skilled unemployment levels and their variation.

To sum up, endogeneizing the search effort of low-skilled workers, and giving them the choice between looking for a job or doing domestic production, introduces a rigidity in the wage bargaining process ${ }^{18}$ that allows our model to reproduce the evolution of unemployment rates and relative wages between 1976 and 1996. As soon as the search effort is taken as constant, relative wages become more flexible and the model predicts a smaller change in unemployment constancy of the low skilled workers' search effort.

${ }^{18}$ Remark that domestic productivity is assumed to be proportional to aggregate productivity, therefore its value increases over time. 
and a larger one in relative wages. If we combine this fixed search effort with an indexation of low-skilled wages to high-skilled ones, the model recovers its ability to reproduce unemployment variation between 1976 and 1996, while loosing its predicting ability for the 1996's levels. Finally, we conclude that the crowding-out of low-skilled workers by high-skilled ones accounts for more than 3 percentage points of the 1996 low-skilled unemployment rate.

\subsection{Policy scenarios}

The persistence of high unemployment rates during the eighties and the nineties, has led the literature to focus on the role of labor market institutions rather than in economic shocks as it was the case during the seventies. Nowadays most of the discussions concerning European unemployment rates focus on the rigidity introduced by labor market institutions whereas the effect of shocks is completely ignored. However, as remarked by Blanchard and Wolfers (2000), while adverse shocks may explain a general increase in unemployment rates, different institutions explain differences in outcomes across countries.

In section 3.2.1 we test the ability of the model to reproduce the variation in unemployment rates and relative wages when a change (a shock) in the proportion of high-skilled workers and in the relative price of new investment goods is introduced. In this section we try to combine both, the effects of shocks and labor market institutions. We consider two policy instruments: the replacement ratio and wage subsidies. As the empirical and theoretical literature has largely documented, the presence of a generous unemployment insurance leads to an increase in equilibrium unemployment rates due to a reduced search intensity and its effect on the bargained wage. On the other hand, the so called "tax wedge" while not directly affecting the unemployment rate has a direct effect on wages.

We use the utility level of high-skilled workers $\mathcal{U}^{h}=\ln \left(C_{t}^{h} / \alpha\right)-N_{t}^{s h} \mathcal{D}\left(e o_{t}\right) / \alpha$ as an indicator of the high-skilled welfare level. In the same way, the utility level of low-skilled, $\mathcal{U}^{l}=\ln \left(C_{t}^{l} /(1-\alpha)\right)$, proxies the welfare level of this type of workers. Because the utility functions are assumed to be welfare indicators, the attention must be focused on the variation of the value function (rather than on the specific value of the utility function). We will compare the final welfare attained by each type of worker under every policy context with respect to the welfare she obtained in the benchmark simulation corresponding to 1996.

Table 7 considers different policy scenarios and compares them to the benchmark simulation 
implemented in section 3.2.1. Comparisons are implemented in a static framework, that is, we compare the final steady states associated to each situation without considering the transitional dynamics.

- We start analyzing a policy measure giving to firms a proportional subsidy of $20 \%$ of lowskilled wages in 1996, this measure being financed through a tax on high-skilled wages. This target policy turns out to be beneficial for both, high and low-skilled workers, in terms of unemployment reductions (this is consistent with the findings of Pierrard (2004) for the Belgian economy). Indeed, the subsidy increases the marginal value the firm obtains from low-skilled workers, which stimulates the opening of simple vacancies and, thus, search efforts in the simple segment. High-skilled unemployment rates slightly fall whereas low-skilled unemployment decreases considerably. In welfare terms, the comparison with respect to the reference simulation, reveals that this measure mainly favors low-skilled workers, whose welfare level clearly raises.

\begin{tabular}{|c|c|c|c|c|c|c|c|c|c|}
\hline & $\begin{array}{l}\text { Prop. of } \\
\text { high-skilled } \\
\text { in the } \\
\text { labor force }\end{array}$ & $\begin{array}{c}\text { Share of } \\
\text { complex jobs } \\
\text { in production } \\
\text { function }\end{array}$ & $\begin{array}{l}\text { Net } \\
\text { Skill } \\
\text { Bias }\end{array}$ & $\begin{array}{l}\text { High-sk. } \\
\text { unempl. } \\
\text { rate }\end{array}$ & $\begin{array}{l}\text { Low-sk. } \\
\text { unempl. } \\
\text { rate }\end{array}$ & $\begin{array}{l}\text { Relative } \\
\text { wage }\end{array}$ & $\begin{array}{c}\text { Job } \\
\text { competition }\end{array}$ & $\begin{array}{l}\text { High-sk. } \\
\text { welfare } \\
\text { indicator }\end{array}$ & $\begin{array}{l}\text { Low-sk. } \\
\text { welfare } \\
\text { indicator }\end{array}$ \\
\hline \multicolumn{10}{|c|}{ Reference Simulation } \\
\hline 1996 & 0.67 & 0.51 & 1.77 & $7.0 \%$ & $21.0 \%$ & $62.1 \%$ & $7.2 \%$ & 0.34 & -0.20 \\
\hline $\begin{array}{c}\text { 1976-96 absolute } \\
\text { deviations }\end{array}$ & +0.45 & +0.32 & +0.25 & +2.1 & +13.3 & -3.4 & +5.8 & -0.25 & -0.08 \\
\hline \multicolumn{10}{|c|}{ Proportional subsidy to low wages of $20 \%$ in 1996} \\
\hline 1996 & 0.67 & 0.52 & 1.80 & $6.8 \%$ & $13.0 \%$ & $71.8 \%$ & $7.2 \%$ & 0.33 & -0.09 \\
\hline $\begin{array}{c}\text { 1976-96 absolute } \\
\text { deviations }\end{array}$ & +0.45 & +0.32 & +0.29 & +2.0 & +5.2 & +6.3 & +5.7 & -0.25 & +0.02 \\
\hline \multicolumn{10}{|c|}{ Replacement ratio of $17 \%$ in 1996} \\
\hline 1996 & 0.67 & 0.52 & 1.82 & $5.7 \%$ & $12.1 \%$ & $54.3 \%$ & $7.0 \%$ & 0.43 & -0.33 \\
\hline $\begin{array}{c}\text { 1976-96 absolute } \\
\text { deviations }\end{array}$ & +0.45 & +0.32 & +0.31 & +0.9 & +4.3 & -11.2 & +5.5 & -0.16 & -0.20 \\
\hline \multicolumn{10}{|c|}{ Replacement ratio of $17 \%$ and a subsidy to low-skilled wages of $20 \%$ in 1996} \\
\hline 1996 & 0.67 & 0.52 & 1.83 & $5.5 \%$ & $8.6 \%$ & $66.6 \%$ & $7.8 \%$ & 0.40 & -0.17 \\
\hline $\begin{array}{c}\text { 1976-96 absolute } \\
\text { deviations }\end{array}$ & +0.45 & +0.32 & +0.32 & +0.6 & +0.9 & +1.1 & +6.4 & -0.19 & -0.05 \\
\hline
\end{tabular}

Table 7: Comparing the reference simulation with different policy scenarios.

- Next we assume a situation where the replacement ratio is set to $17 \%$ (the half of its 
actual value) in 1996. This measure mainly affects low-skilled workers, whose consumption is constrained by their revenue. Reducing the replacement ratio implies a reduction in the reservation wage. This stimulates employment since firms can now offer lower wages and low-skilled workers search more intensively for a job. Both unemployment rates fall, however, only high-skilled welfare is improved, since low-skilled workers suffer from an important loss in their revenue that results in a downturn of their consumption level.

- We then combine the two previous policy measures. This policy mix leads to a Pareto improving situation where the unemployment rates of both types of households are lower and their welfare is improved with respect to the reference simulation. The reduced replacement ratio stimulates employment, leading to a decrease in unemployment rates. At the same time, the subsidy to low-skilled wages avoids the loss in the welfare suffered by unskilled workers due to the downturn in their revenue.

To sum up, if the increase in the proportion of high-skilled workers and the decrease in the relative price of new investment goods, i.e. two shocks observed over the past decades, had been associated to less rigid labor market institutions (eg.: less generous unemployment insurance) we would have observed a smaller increase in unemployment rates. Moreover, table 7 suggests that an appropriate policy mix could have led to this result without implying any lost in welfare. Of course, policies based on subsidies to low-skilled wages are, at best, effective in the short and medium term (see Pierrard (2004)). However, in the long-run, an increase in the proportion of skilled in the total labor force seems more appropriate. More precisely, as suggested in various studies (see for example Cockx and Dejemeppe (2004)) a human capital investment policy ${ }^{19}$ would mitigate skill mismatch and job competition and it would stimulate the appearance of technological sites that develop productive activities.

\section{Conclusions}

Over the last 30 years, European average unemployment rates and, especially, low-skilled unemployment rates have followed an increasing trend. Two reasons are traditionally put forward to explain this rise: (i) the adoption of new technologies being more demanding in skilled labor, combined with a rigidity in relative wages over the time, has resulted in the appearance of

\footnotetext{
${ }^{19}$ According to CESRW (2001) only $3.7 \%$ of Belgian unemployed workers had participated in a training programme in 2000 .
} 
skill mismatch effects; (ii) aggregate technological shocks implying a decrease in the total labor demand have crowded out lower educated workers by higher educated ones (job competition).

Models built up to now were unable to capture simultaneously the stylized facts observed in most European economies: the rise in the overall unemployment rate, the more important increase in low-skilled unemployment rates and the stability of relative wages. Our paper focuses on these issues. We build an intertemporal general equilibrium model based on Pierrard and Sneessens (2002) but incorporating separate wage bargaining for all workers, endogenous search efficiencies on each labor market segment and endogenous skill-biased technological progress. We calibrate it on the basis of Belgian data and test its ability to reproduce both the situation in Belgium in 1996 and the observed variation in economic magnitudes between 1976 and 1996. Our theoretical setup performs well in both cases. Evidently a non negligible part of the predicting ability of the model is due to the effect of embodied technological progress on the Cobb-Douglas productivity coefficients. We also find that relative wage stability and job competition have a key role in explaining the variation (rise) in low-skilled unemployment rates over the past decades, while the effect of low-skilled discouragement mainly affects unemployment levels rather than unemployment variations.

Our model constitutes a successful attempt to take simultaneously into account the stylized facts characterizing most European countries over the last decades. However there are several limiting assumptions that we need to analyze in detail in order to improve our understanding of these phenomena. First of all, this paper assumes an exogenous evolution of the proportion of highskilled in the labor force, $\alpha$. Evidently, an interesting extension would consist in endogeneizing the evolution of $\alpha$. In this new context, an acceleration of embodied technological progress should stimulate workers to educate themselves and $\alpha$ would increase endogenously between 1976 and 1996. Second, our paper ignores the effect of growth. To have a more complete representation of the economy and to improve the comprehension of the stylized facts that have characterized its evolution, we should extend the model to an endogenous growth context. Finally, it might be interesting to check whether results are robust to a change in the functional form of the production function. This approach is however limited by the fact that, for Belgium, we only have estimations for the Cobb-Douglas productivity coefficients. To adopt a different functional form, we would have to use the estimations provided in the literature for other countries (in Krusell et al. (2000) the authors use U.S. data to estimate the productivity coefficients of a nested CES production function). 


\section{References}

Albrecht, J., and S. Vroman. 2002. "A matching Model with Endogenous Skill Requirements." International Economic Review 43:283-305.

Andolfatto, D. 1996. "Business cycles and labour-market search." American Economic Review $86(1): 112-132$.

Autor, D.H., L.F. Katz, and A.B. Krueger. 1998. "Computing inequality: Have computers changed the labour market?" Quarterly Journal of Economics 113:1169-1213.

Berman, E., J. Bound, and Z. Griliches. 1994. "Changes in the demand for skilled labor within U.S. manufacturing: evidence from the Annual Survey of Manufacturers." Quarterly Journal of Economics 109:367-397.

Blanchard, O., and J. Wolfers. 2000. "The Role of Shocks and Institutions in the Rise of European Unemployment: The Aggregate Evidence." The Economic Journal 110 (462): 1-33 (March).

Boucekkine, R., F. del Rio, and O. Licandro. 2003. "Embodied Technological Progress, Learning and the Productivity Slowdown." Scandinavian Journal of Economics 105:87-98.

Bresnahan, T.F., E. Brynjolfsson, and L.M. Hitt. 2002. "Information Technology, Workplace organization, and the Demand for skilled Labor: Firm-Level Evidence." The Quarterly Journal of Economics 117 (1): 339-376.

Burdett, K., and D. Mortensen. 1998. "Wage Differentials, Employmer Size and Unemployment." International Econoomic Review 39 (2): 257-273.

Buttler, F., and M. Tessaring. 1993. "Human Kapital als Standortfaktor." Mitteilungen aus der Arbeitsmarkt und Berufsforschung 26, no. 4.

Caroli, E., and J. Van Reenen. 2001. "Skilled Biased Technological Change? Evidence from a Pannel of British and French Establishments." Quarterly Journal of Economics 116 (4): 1449-1492.

CESRW. 2001. "Rapport sur la Situation Economique et Sociale de la Wallonie." Conseil Economique et Sociale de la Région Wallonne, Décembre, 118-119.

Cockx, B., and M. Dejemeppe. 2004. "Do the Higher Educated Unemployed Crowd out the Lower Educated Ones in a Competition for Jobs?" fothcoming in Journal of Applied Econometrics. 
Collard, F., R. Fonseca, and R. Muñoz. 2002. "Spanish unemployment persistence and ladder effect." Centre for Economic Performance, London School of Economics and Political Science.

Delmotte, J., G. Van Hootegem, and J. Dejonckheere. 2001. "Les entreprises et le recrutement en Belgique en 2000." HIVA, Katholieke Universiteit Leuven, and UPEDI.

Denolf, L., J. Denys, and P. Simoens. 2001. "Les Entreprises et le Recrutement en Belgique en 2000." HIVA, Katholieke Universiteit Leuven.

Dolado, J., F. Felgueroso, and J. Jimeno. 2000. "Youth labour markets in Spain: Education, training and crowding-out,." European Economic Review 44:943-956.

Dolado, J., M. Jansen, and J. Jimeno. 2002. "A matching model of crowding out and on the job search (with an application to Spain)." mimeo.

Fonseca, R., B. Maillard, and H. Sneessens. 1998. "Structural Adjustment and Unemployment Persistence: The Case of France and Spain." Robert Schuman Center Discussion Paper, no. $98 / 47$.

Forgeot, G., and J. Gautié. 1997. "Insertion Professionnelle des jeunes et processus de déclassement." Economie et Statistique 4/5 (304-305): 53-74.

Gautier, P.A. 2002. "Unemployment and Search Externalities in a Model with Heterogeneous Jobs and Heterogeneous Workers." Economica 69:21-40.

Greenwood, J., Z. Hercowitz, and P. Krussel. 1997. "Long-Run Implications of InvestmentSpecific Technological Change." American Economic Review 87 (3): 342-362.

Hall, R. 2005. "Employment Efficiency and Sticky wages: evidence from Flows in the Labor Market." The Review of Economic and Statistics 87 (3): 397-407 (August).

Hall, R., and P. Milgrom. 2005. "The Limited Influence of Unemployment on the Wage Bargain." Mimeo, Stanford University, September.

Hartog, J. 2000. "Over-education and earnings: where are we, where should we go?" Economics of Education Review 19:131-147.

Krusell, P., L.E. Ohanian, J.V. Rios-Rull, and G.L. Violante. 2000. "Capital skill complementarity and inequality: A macroeconomic analysis." Econometrica 68 (5): 1029-53.

Lindquist, M. 2004. "Capital-Skill Complementarity and Inequality over the Business Cycle." Review of Economic Dynamics 7 (3): 519-540 (July). 
Machin, S., and J. Van Reenen. 1998. "Technology and changes in skill structure: Evidence from seven OECD countries." Quarterly Journal of Economics 113:1215-44.

Mairesse, J., G. Cette, and Y. Kocoglu. 2000. "Les Technologies de l'Information et de la Communication en France: Diffusion et Contribution à la Croissance." Economie et Statistique 9/10 (339-340): 117-146.

Manacorda, M., and B. Petrongolo. 1999. "Skill Mismatch and Unemployment in OECD countries." Economica 66:181-207.

Merz, M. 1995. "Search in the labor market and real business cycle." Journal of Monetary Economics 36:269-300.

Muysken, J., and B. ter Weel. 1999. "Overeducation, Job Competition and Unemployment." MERIT DP 99032, Maastricht University.

Nickell, S., and G. Quintini. 2001, 4 September. The Recent Performance of the UK Labor Market. Paper presented in the Economics Section of the British Association for the Advanement of Science.

OECD. 1996, July. "OECD Employment Outlook.” Technical Report, OECD.

Patacchini, E., and Y. Zenou. 2003. "Search Intensity, Cost of Living and Local Labor Markets in Britain." IZA Discussion Paper No 772, Bonn, May.

Petrongolo, B., and C. Pissarides. 2001. "Looking Back into the Black Box: a Survey of the Matching Function." Journal of Economic Literature 39:390-431.

Pierrard, O. 2004. "Impacts of Selective Reductions in Labor Taxation." mimeo. Catholic University of Louvain.

Pierrard, O., and H. Sneessens. 2002. "Low Skilled Unemployment, Biased Technological Change and Job Competition." mimeo, IRES, Université Catolique de Louvain.

Pissarides, C. 2000. Equilibrium Unemployment Theory. Edited by MIT Press. Cambridge, Massachusetts: MIT Press.

Postel-Vinay, F., and J.M. Robin. 2002. "Equilibrium Wage Dispersion with Worker and Employer Heterogeneity." Econometrica 70 (6): 2295-2350.

Shimer, R. 2005. "On-the-Job Search and Strategic Bargaining." Mimeo, University of Chicago.

Sneessens, H., and F. Shadman. 2000. "Analyse macro-économique des effets de réductions ciblées des charges sociales." Revue belge sécurité sociale, no. 3:613-630. 
Van der Linden, B., and E. Dor. 2001. "Labor market policies and equilibrium employment: Theory and application for Belgium." IRES Discussion Paper. Catholic University of Louvain., no. 2001-05. 